\title{
Para um Diverso Decameron
}

\author{
Renzo Bragantin ${ }^{*}$
}

RESUMO: Que o Decameron tenha sido fortemente influenciado pela Comédia dantesca (e parcialmente também pelo Cancioneiro de Petrarca) é fato notório. Em geral, porém, essa influência é considerada apenas nos termos de uma veneração de Boccaccio por Dante, sem que se tenha alguma vez questionado se Boccaccio não interviria para questionar, também, em função da própria poética, algumas das teses básicas do poema dantesco. Propõe-se neste ensaio precisamente essa tarefa de tentar demonstrar como Boccaccio, ao intervir em tais teses, questiona seus princípios fundamentais, em primeiro lugar aquele do estatuto de verdade, a todo momento mencionado por Dante e proposto a seu leitor, e que Boccaccio submete a um exame atento, por vezes crítico. Isso se dá, sobretudo, em alguns trechos do Decameron, nos quais Boccaccio fala diretamente, sem a mediação dos próprios narradores (por exemplo, na Introdução à IV jornada); mas também pode ser identificado nas premissas e conclusões dos narradores às próprias narrativas. Nelas, a intangibilidade da verdade, e ao mesmo tempo a necessidade de interpretar a realidade, submetida a um constante escrutínio, propõe-se não como modelo oposto, mas decerto radical e problematicamente diferente daquele que a experiência dantesca sugere.

PALAVRAS-CHAVE: Decameron; Giovanni Boccaccio; Dante Alighieri; Francesco Petrarca; modelos narrativos; verdade; interpretação.

\footnotetext{
* Università degli Studi di Roma, "La Sapienza"
} 
ABSTRACT: Che il Decameron sia stato largamente influenzato dalla Commedia dantesca (e anche, in parte, dal Canzoniere petrarchesco) è risaputo. Ma generalmente tale influenza è considerata solo alla stregua di una venerazione di Boccaccio per Dante, senza che ci si sia domandato se Boccaccio anche non intervenga a ridiscutere, in funzione della propria poetica, alcuni assunti basilari del poema dantesco. Il saggio si propone appunto tale compito, tentando di dimostrare come Boccaccio, intervenendo su tali assunti, ne interroghi i principi di fondo, primo tra tutti quello dello statuto di verità, a ogni momento rilanciato da Dante e proposto al proprio lettore, e sottoposto da Boccaccio a un'attenta, e talora critica, verifica. Ciò avviene soprattutto in alcuni brani del Decameron in cui Boccaccio parla direttamente, senza la mediazione dei propri narratori (a esempio, nell'Introduzione alla IV giornata); ma è anche individuabile nelle premesse e conclusioni dei narratori ai propri racconti. In esse l'inattingibilità della verità, e allo stesso tempo la necessità di interpretare la realtà, sottoposta a un incessante scrutinio, si propone come un modello non opposto, ma certo radicalmente e problematicamente altro da quanto suggerito dall'esperienza dantesca.

PAROLE CHIAVE: Decameron; Giovanni Boccaccio; Dante Alighieri; Francesco Petrarca; modelli narrativi; verità; interpretazione.

ABSTRACT: It is a well known fact that Boccaccio's The Decameron has been strongly influenced by Dante's The Divine Comedy and Petrarch's The Canzoniere. Yet, such an influence, particularly as Dante is concerned, is generally considered a symptom of Boccaccio's veneration for his great predecessor. Rarely have scholars asked themselves whether Boccaccio, following Dante's path, also disputes some fundamental points of Dante's poem. The essay tries to demonstrate how Boccaccio faces this problem as well as how Boccaccio critically queries the fundaments of truth in the Divine Comedy. This can be conspicuously observed in parts of The Decameron where the author speaks directly to the reader (particularly in the Introduction to day IV). However, it can also be identified in other parts of the book, 
as it is the case with the assumptions and conclusions of the single tales. If not a totally opposite model to Dante's poem, these sections of Boccaccio's masterpiece have to be regarded as a radically different literary experience.

KEYWORDS: Decameron; Giovanni Boccaccio; Dante Alighieri; Francesco Petrarca; narrative models; truth; interpretation. 
ntre os inquestionáveis progressos efetuados nos últimos tempos pela crítica boccacciana, inclui-se a indicação do caráter, por assim dizer, extranovelístico do acervo da novelística por excelência da literatura italiana e europeia. Não raramente o Decameron foi definido como um "tratado" (inclusive por mim), definição que evidentemente não pretende ser omnicompreensiva, muito menos conclusiva, mas que talvez tenha a vantagem de atrair a nossa atenção para aspectos até há pouco tempo menosprezados (e que ainda não se tornaram base perceptiva comum) da obra-prima de Boccaccio; um deles é precisamente aquele que o qualifica como um tratado (em forma narrativa) que tem por objeto os mores (costumes) ${ }^{1}$, a começar pelos mores relativos ao amor (BATTAGLIA RICCI, 2013, p. 27-56). Sem pretender apresentar formulações definitivas, poderíamos afirmar que o Decameron é um texto que, por

1 Da expressão latina de Cícero o tempora, o mores lat. (“oh tempos, oh costumes!”), repetida em várias orações; hoje parodicamente repetida (Nota do tradutor). 
meio de complexas estratégias narrativas, discute temas da filosofia moral da Idade Média que estava prestes a chegar ao fim. Para reconsiderar as coisas também sob este aspecto, contribui antes de tudo a mise en page do autógrafo que, como evidenciaram Teresa Nocita e Lucia Battaglia Ricci, apresenta - mediante uma atenta articulação dos planos do discurso, que contempla o uso de letras capitulares de diferentes tamanhos (em vermelho e azul turquesa) a fim de demarcar as várias seções do texto (início das jornadas, incipit e partes liminares de cada novela, conclusão de cada jornada, baladas no fim de cada jornada) -, uma paragrafação da composição, visando conferir um peso relevante aos parágrafos introdutivos de cada narrativa, para indicar que essa mesma narrativa tenderá a se colocar em função demonstrativa (harmônica ou contrastante) em relação a eles: ${ }^{2}$ peculiaridade que, diga-se de passagem, nota-se, embora sem perfeitas coincidências, também nos outros códices da protodifusão (o assim chamado fragmento magliabechiano: Firenze, Biblioteca Nazionale Centrale, II, II 8; ${ }^{3}$ Piacenza, Biblioteca Passerini Landi, cód. Vitali 26, testemunho fragmentário; Paris, Bibliothèque Nationale de France, Italiano 482). ${ }^{4}$ Isso significa que, pelo menos na difusão do texto ocorrida entre a parábola biográfica de Boccaccio, a indicação de leitura fornecida pela demarcação inicial pretendida pelo autor é entendida como fato distintivo do Decameron e de suas estratégias de apresentação - viceversa, já na primeira difusão, nota-se uma consistente obliteração de tal peculiaridade (CURSI, 2013, p. 109). Trata-se de um recurso que mesmo o leitor do século XXI, embora não possa absolutamente renunciar a suas perspectivas de leitura, deve ter em conta, se quiser, diante dessas divergências, conferir ao texto a riqueza que a história de sua fruição lhe atribuiu.

Abro um breve parêntese para enfatizar que, já em 1927, Barbi advertia sobre o que tinha de ser feito, ou seja, proceder a uma comparação tão completa quanto possível entre todos os testemunhos do Decameron, fato que se tem demonstrado uma tarefa cada vez mais urgente (BARBI, 1973, p. 35-85). Tendo recentemente efetuado (em função de uma monografia decameroniana em que estou trabalhando atualmente) uma análise comparativa completa entre o manuscrito italiano de Paris e o autógrafo Hamiltoniano, creio que posso afirmar que o texto, como o lemos hoje, segundo a benemérita edição de Branca (BOCCACCIO, 1980), deve ser revisto em muitos e não secundários pontos, posto que, independentemente do fato inegável de que os autores são sempre copistas pouco confiáveis por si só, Boccaccio, como justamente afirmou Branca vária vezes, exerce essa função de modo particularmente descuidado e apressado,

2 Cfr. NOCITA, 1999; BATTAGLIA RICCI, 2000, 141-49; também RAFTI, 2001, part. pp. 7-10; MALAGNINI, 2003. A paragrafação foi adotada nas seguintes edições: HERNÁNDEZ ESTEBAN, 1994; FIORILLA, 2011; QUONDAM, FIORILLA, ALFANO, 2013.

3 Sobre a peculiar natureza deste testemunho, cfr. Cursi (2007, p. 21-31), que deve ser integrado, em relação à identificação do copista, com Cursi (2013, p. 111-112).

4 Para uma exata ilustração do sistema de paragrafação nos códices da tradição, em relação à proto e primeira difusão, cfr. Cursi (2007, p. 155-159). Para a fidelidade dos testemunhos da protodifusão na mise en page concebida por Boccaccio, cfr. Cursi (2013, p. 110-128). 
de maneira que em vários trechos, no mínimo duvidosos, e em outros certamente errôneos, a versão do autógrafo Hamiltoniano deve ser corrigida, obviamente somente quando seja possível excluir que o trecho em discussão esteja associado a variantes de autor, recorrendo-se ao manuscrito de Paris (mas, naturalmente o exame deve ser ampliado a outros testemunhos importantes). ${ }^{5}$ Não se contam os casos de saut du même au même, erros de antecipação ou de repetição e versões piores que permeiam o autógrafo. Quanto ao manuscrito de Paris, considero que defini-lo como primeira redação do Decameron, como defendem Vitale e Branca (2002), seja sem dúvida excessivo: se pensarmos nos casos que frequentemente são citados para justificar tal qualificação (Ariosto, Manzoni, etc.), poderíamos falar quando muito de uma diferente elaboração (termo que a meu ver não deve ser confundido com o de redação), conceito que acentua o fato de que a fisionomia do texto não é alterada de modo tão evidente que leve a pensar em diferentes fases, agora sim, redacionais: as quais são caracterizadas, no iter textual, pela mudança acentuada (e muitas vezes coerentemente estendida a todo o texto) da facies linguística (no sentido fonético e/ou morfológico-sintático), deslocamento de segmentos mais ou menos amplos da escrita, expansão ou condensação do texto, eventual diferença de seriação de trechos (para obras em que possam ser isolados) etc. Se fizermos uma comparação com o que nos é possível conhecer das cartas petrarquistas, em relação aos Rerum vulgarium fragmenta (que talvez seja o confronto mais coerente no caso em questão), creio que se possa dizer que, não se verificando entre o códice italiano de Paris e o Hamiltoniano as condições acima referidas, encontramo-nos, com os testemunhos mais importantes do Decameron, diante de uma fenomenologia totalmente diferente, à qual não convém a qualificação de redação diferente. ${ }^{6}$

Que o Decameron seja o primeiro livro novelístico de autor da nossa literatura já é um consenso generalizado. Uma prova anterior importante também para o próprio texto boccacciano, como o Novellino, denuncia, de fato, já pelo título aposto no manuscrito mais antigo (Libro di novelle e di bel parlare gientile ), sua natureza de texto antológico, embora nesse caso se possa admitir identificar certa individualidade autoral: ${ }^{7}$ mas se trata de autor que se baseia em narrações pré-existentes, não de autor que assume em primeira pessoa um projeto literário ambicioso, e incomparável respeito às tentativas anteriores ou coevas. Apesar desse mérito indiscutível, é certo que Boccaccio recorreu ao manuscrito anterior, como a tantos outros diferentes que pôde conhecer (clássicos e medievais), para alinhavar um livro que, baseado em tantos e diversificados materiais, não se parece com nenhum outro.

\footnotetext{
5 Sobre a questão, limito-me a indicar as contribuições mais recentes e importantes (todos com bibliografia pregressa): Breschi (2004); Fiorilla (2010, 2013). Tenha-se presente que a edição de Quondam, Fiorilla e Alfano (BOCCACCIO, 2013) já corrige em vários pontos, recorrendo ao manuscrito de Paris e segundo as modalidades indicadas, o texto estabelecido por Branca.

$6 \mathrm{Na}$ impossibilidade de fornecer adequado suporte bibliográfico sobre o Petrarca vulgar, limito-me a indicar Santagata (PETRARCA, 2004) e Paolino (PETRARCA, 2000) (para a parte relativa ao Cancioneiro).

7 Cfr. a Nota al testo in CONTE 2001, pp. 267-93.
} 
A base para se conduzir um adequado discurso sobre os modelos narrativos do Decameron é naturalmente um comentário atualizado da obra, a este ponto inderrogável: digo atualizado porque aquele histórico e ainda hoje indispensável de Branca (BOCCACCIO, 1980) não pôde sempre contemplar, em suas últimas versões, as inúmeras novidades que se somaram sobre a obra-prima de Boccaccio, nomeadamente em relação à descoberta ou achado das fontes, cujo espectro é demasiado amplo, e cuja utilização é excepcionalmente sofisticada; por outro lado, a citada recente edição de Quondam, Fiorilla e Alfano (BOCCACCIO, 2013) não oferece qualquer informação sobre tal vertente (a não ser pelo que em parte foi louvadamente suprido pela Ficha introdutiva preposta por Alfano a cada jornada). Tão sofisticada, cumpre dizer, essa utilização, que a muitos parece, e a meu ver erroneamente, que se tem insistido demasiadamente nesse ponto crucial. Partindo do princípio que o achado ou a descoberta das fontes sejam obrigatórios para efeitos de comentário (o que nem sempre acontece), não pretendo com isso defender nem a segura identificabilidade delas (que em Boccaccio, como em todos os autores culturalmente ricos, quase nunca são isoláveis), nem muito menos conferir àquela identificação um valor resolutivo, como se a crítica decameroniana encontrasse nela seu máximo exercício; mesmo porque o autor intervém em vários níveis, e neles a textualidade identificável (quando existe) é apenas uma das componentes. Mas saber como Boccaccio manuseou suas fontes de inspiração, como as reelaborou e orientou, apresentando ao leitor um texto excepcionalmente estratificado, no qual essas fontes, interagindo com o conjunto, cooperam para fazer do Decameron um texto com propósitos bem diferentes do mero entretenimento, não me parece um detalhe irrelevante.

Se desprezarmos estes fatos, agiremos como se não soubéssemos quão multiforme, e por tantos aspectos imprevisivelmente cativante, seja a cultura de Boccaccio. Claro, falta-lhe a solidez doutrinal e o rigor mental de Dante, e Boccaccio não tem a sensibilidade filológica e a inatingível cultura clássica de Petrarca. Mas isso não diminui sua força como leitor, não apenas onívoro, mas perspicaz, capaz de tirar dos textos as lições mais impensáveis: o que torna muitas vezes difícil a identificação correta de suas fontes. Retornarei a esse ponto. No momento, acho necessário aprofundar um fato que deveria ser claro a muitos, mas que ainda não se tornou consciência comum: a saber, a natureza extremamente complexa do livro, e, logo, do uso que ele faz de seus modelos. Até há não muito tempo, o fato de o Decameron ter sido rotulado como texto de entretenimento ofuscou o projeto maior do texto; também por esse motivo um olhar atento para o autógrafo, compaginado nos moldes de um texto universitário, mostra-se instrutivo. ${ }^{8}$ E, diga-se de passagem, já a primeira fruição da obra, que Branca relacionou com ambientes 
predominantemente mercantis, foi direcionada a mais heterogêneos e articulados percursos pelas recentes análises de Marco Cursi (2007), que submeteu a crivo clínico 60 manuscritos do Decameron, da protodifusão (1360-1375) à segunda difusão (1426-1490). De suas pesquisas emerge que os copistas por paixão não podem ser definidos figuras predominantes, mas que, pelo contrário, a eles está associada uma relevante presença de copistas a pagamento, isto é, de copistas profissionais ou semiprofissionais, o que leva a repensar o problema da produção e da circulação da obra (CURSI, 2007, p. 134-142). Segue-se que, dando à sua obra-prima aquele aspecto, Boccaccio quis advertir seus leitores, que, contudo, tiveram dificuldades em compreender profundamente a radicalidade de suas intenções, ainda mais porque tal radicalidade coloca-se sob a égide irônica da enganosa simplicidade de acesso. A atitude condescendente historicamente reservada amiúde ao Decameron não deve surpreender, se pensarmos que, desde as primeiras criações romanças, a narratio brevis luta para ocupar um espaço entre os gêneros literários dotados de maior prestígio - entre todos, a épica e a lírica. A consciência do laboratório de Boccaccio permite hoje, multiplicados os estudos nessa direção, efetuar notáveis correções nessa errônea abordagem do texto. ${ }^{9}$

Que entre os modelos, um lugar importante caiba também a Petrarca parece indiscutível, se bem que uma pesquisa sistemática nesse sentido ainda deve ser feita. Branca refere-se justamente, em seu comentário, como o soneto introdutivo do Cancioneiro tenha deixado suas sementes já no proêmio do Decameron, inclusive nas referências lexicais (a começar pelo primeiro juvenil erro petrarquista e pela primeira juventude boccacciana). Estou, porém, convencido de que não é tanto ou somente esse o território que se deve percorrer para encontrar repercussões petrarquistas ativamente operantes no Decameron, mas que se deve buscá-las, ao menos em igual medida, nas obras latinas, em África e em algumas epístolas do Familiares (VELLI, 1995, p. 237-243).

Bem diferente, e amplamente documentado e analisado por diferentes pontos de vista, é o peso exercido pelo modelo dantesco. ${ }^{10}$ Mas aqui cabe um esclarecimento. Depois de reunido o indispensável repertório das repercussões intertextuais, só estamos no início do trabalho, sobretudo quando se trata de um insuperável gênio da paródia como Boccaccio. Com ele, é mais que oportuno conferir ao termo "paródia" seu significado mais amplo e incisivo de reescrita, sempre problematicamente configurada, supondo que o Decameron ofereça também exemplos de paródia no sentido mais comumente aceito de rebaixamento, obviamente, paródico. Mas com Dante o empenho de Boccaccio, por razões que não cabe aqui ser discutidas, é máximo,

9 Parte fundamental de tal acerto de rumo cabe ao reconhecimento, muito recente, dos muitos autógrafos boccacciani definidos como editoriais (para a distinção das edições autorais autógrafas, cfr. Battaglia Ricci, 2010, part. p. 123-128); para ambas as tipologias, cfr. o catálogo de Cursi e Fiorilla (2013).

10 Basta ao menos pensar nos estudos de Hollander (1997) e nas indicações de Bettinzoli, cfr. HOLLANDER 1997;

BETTINZOLI 1981-1982 e 1983-1984, sem se esquecer de DELCORNO 1979. 
e traduz-se, particularmente no Decameron, em um verdadeiro corpo a corpo com a Comédia. Cumpre acrescentar a propósito que sua atitude em relação a toda a obra de Dante registra, ao longo dos anos, alguns acertos de rumo, que não devem ser enfatizados nem ignorados; ${ }^{11}$ posto que se está tornando uma moda buscar, na atividade literária de Boccaccio, uma progressiva "dantização", a que se uniria uma igualmente visível "petrarquização", eu sugeriria cautela e oportuna moderação diante do risco de sedução que tais sereias exercem. Ao longo de tantos séculos, leitores absolutamente nada ingênuos não teriam entendido coisa alguma? Abater os falsos mitos é sacrossanto, desde que se abdique de venerar apressadamente os novos; sobretudo se as novas sereias não levarem sempre em devida conta a especificidade do sistema literário da última Idade Média.

Para dispor as coisas sob o correto ponto de vista, cumpre antes de tudo ressaltar como a posição de Boccaccio enquanto autor, em relação ao próprio texto, não possa ser comparada nem com a de Dante nem com a de Petrarca. Boccaccio não está nem no interior do seu libro como auctor e nem como agens - como no caso de Dante (CONTINI, 1970); nem se pode, por outro lado, pensar que seu distanciamento das tempestades amorosas juvenis, segundo o propósito inicial do proêmio, possa ser apresentado com o mesmo caráter exemplar de árdua conquista de uma mutatio vitae com base agostiniana, tal como acontece no Cancioneiro (SANTAGATA, 2004, p. 41-99). Sua posição em relação ao círculo dos narradores não lhe confere poder testemunhal comparável ao dos outros dois grandes: as duas breves menções em I Intr., 16, 18, precisamente em sua cronística elucidação, não permitem assimilações com a enormidade daquelas experiências. Boccaccio é, sobretudo, exterior ao seu livro, e só raramente se permite intervir em seus propósitos para defender a própria obra, e para tentar oferecer as corretas perspectivas de leitura. Em outras palavras, Boccaccio esconde-se por trás da voz dos narradores no Decameron; já Dante, pelo contrário, está sempre no centro da Comédia, e Petrarca mantém firmes as rédeas do seu discurso penitencial. Todavia, precisamente aqui subjaz um risco de subavaliar os procedimentos parodísticos de Boccaccio. Hollander (1997, p. 21-52) definiu sua relação com Dante como "imitative distance" e, mais detalhadamente, propôs que se lesse a história de Ser Ciappelletto e a novela de Frate Cipolla, respectivamente, como reescritura do canto de Brunetto (Inferno XV) e como paródia de Dante, autor da Comédia. Talvez as teses de Hollander sejam extremistas (para se poder falar de reescritura e paródia são necessárias evidências textuais que nos casos indicados não me parecem sempre manifestas), e o mesmo estudioso admite que suas tomadas de posição podem ser consideradas “over-ingenious" (Ibid.,

11 Para uma rápida orientação sobre esse último ponto, limito-me a indicar Fumagalli (2013) (com bibliografia precedente). Observações pertinentes também em Battaglia Ricci (2013, p 148-56). 
p. 27); mas a essência do seu discurso mostra-se sem dúvida compartilhada. Creio que se possa, sobretudo, concordar com sua afirmação, segundo a qual alusões e citações a respeito da Comédia são feitas no Decameron sob uma lente frequentemente crítica. De fato, não devemos dar demasiada fé a Boccaccio quando segue o percurso de Dante, porque na maioria dos casos ele não está procurando uma conciliação ou uma adaptação em relação ao seu texto. Nesse sentido, penso que, depois de constatada a grandeza do diálogo intertextual que o Decameron mantém com a Comédia, deve-se começar a colocar em relevo alguns pontos cruciais que parecem, reescrevendo-os, recolocar em discussão assuntos centrais do texto dantesco.

Comecemos pelos dados mais simples e do conhecimento de todos: o Decameron é constituído por cem novelas (na verdade, são cento e uma, contando aquela sobre as patas, que tem um papel decisivo), assim como os cantos da Comédia. A data da grande peste, o ano de 1348 , cai no trigésimo quinto ano de idade de Boccaccio, logo, no mesmo ponto da parábola biográfica de Dante, autor da Comédia. O conjunto desses dados remeteria a uma espécie de sentido de ordem e simetria comparável ao que se pode reconhecer em Dante. E isso é precisamente o que muitos e conceituados leitores decameronianos pensam. O que inevitavelmente leva (e, de fato, levou) à conclusão de que, seguindo o ritmo ascensional da Comédia, Boccaccio apresentaria seu livro como um caminho de árdua progressão no sentido de valores morais mais elevados. Mas esquecemo-nos de que tais valores são experimentados por Dante, inclusive como protagonista (agens), não apenas como autor (auctor); e que, pelas razões já expostas, a posição de Boccaccio não é comparável. Segundo a leitura longamente dominante, Ciappelletto seria o perfeito oposto de Griselda. O que, relativamente a esta última novela, é verdade quanto aos fatos, não quanto à voz (a de Dioneo) que a relata; é verdade pelo enunciado, não pela enunciação. O que é demonstrado pelo comentário escarnecedor do narrador na conclusão do episódio:

Que dizer desse caso, a não ser que nas casas pobres também caem do céu espíritos divinos, assim como nas régias caem uns que seriam mais dignos de guardar porcos que de exercer o poder sobre seres humanos? Quem, senão Griselda, teria conseguido suportar as rígidas e inauditas provas impostas por Gualtieri, não só sem lágrimas como também com um sorriso no rosto? Se bem que talvez não tivesse caído mal a Gualtieri topar com uma que, ao ser expulsa de casa só com uma camisa, tivesse arranjado outro que lhe sacudisse a samarra e lhe desse um belo vestido. $(2013, \text { p. } 621)^{12}$

12 Será utilizada, para as citações dos trechos de o Decameron, a tradução feita por Ivone C. Benedetti. BOCCACCIO, Giovanni. Decameron. Rio Grande do Sul: L\&PM Editores, 2103 
Tudo isso não se lê obviamente na versão da história fornecida por Petrarca, que, de fato, embora sem conhecimento das nossas fáceis distinções teóricas, escreve, na carta a Boccaccio que acompanha a tradução latina (Seniles, XVII 3): "Historiam tuam, meis verbis explicui" ("A tua história, explicada pelas minhas palavras" -PETRARCA, 2006, p. 540), mostrando com isso entender profundamente a diferença entre enunciado e enunciação. Retornando à relação com Dante, devemos ter em mente a advertência de Hollander, segundo a qual Boccaccio submete a escrutínio dois postulados fundamentais da Comédia: a veracidade poética e sua aplicabilidade moral. Não só Dante, como se verá, está implicado nessa rede de referências intertextuais ou interdiscursivas, mas não há dúvida de que ele seja um dos principais alvos da reescritura boccacciana. Tal reescritura situa-se em diferentes níveis, dos quais acho importante analisar alguns entre as implicações mais elusivas.

A elusividade deve, por outro lado, fazer as contas com uma difícil alusividade, que daquela constitui ingrediente essencial. Explicarei limitando-me a indicar um único caso, que resulta, porém, de amplo alcance, estendendo-se na realidade a todo o texto. Durante séculos, o Decameron foi lido como um livro de incitamento ao prazer erótico e sexual, dando origem ao abuso do termo "boccaccesco" (que aqui, por boas razões, não se adotará), usado em função exclusiva por aqueles que, evidentemente, nunca refletiram, como se há de fazer, sobre o livro que tem por título Decameron, limitando-se simplesmente a ler as histórias que mais tenderiam para aquela vertente. Vertente que naturalmente existe, mas que é uma componente do livro, componente que, sobretudo, deve, como outras, ser tida em conta como estratégia de intervenção da literatura na realidade que o próprio Boccaccio inaugurou; mas que, precisamente pelo fato de se articular em tais estratégias, não pode aspirar a ter representação dominante, muito menos exclusiva. Sei bem que subavaliar o coté erótico-sexual seria um erro gigantesco, porque iria em certo sentido contra a lógica do livro. Mas contra esta, iria também uma leitura que lutasse para se dar conta do fato de que, precisamente em relação a seu relativismo processual, o texto é confiado, pela sua plena inteligência, à utilização que o leitor possa fazer dele, sendo deixado como único responsável pelos acontecimentos; logo, em se tratando de um caminho que segue na direção de valores moralmente elevados, é o leitor (êmulo nesse sentido dos narradores do grupo) que se deve tornar o experimentador, conhecendo o livro intus et in cute. Há de se identificar aqui, na centralidade da figura do leitor, um dos máximos pontos de distância de Dante, embora também ele invoque o leitor continuamente (BATTAGLIA RICCI, 1987, p. 191-196). Mas a direção é, em certo sentido, contrária, porque o leitor é em Dante exortado a 
acreditar na história da viagem inclusive em suas implicações menos críveis (“À verdade com cara de mentira/ sábio serás se o teu silêncio votas,/ pois, sem culpa, por vez vergonha vira. / Mas aqui não me calo e, pelas notas/ desta Comédia, meu leitor, te Juro", etc.; Inf., XVI 124-28), ${ }^{13}$ e a efetuar por conseguinte o necessário percurso de purificação; enquanto em Boccaccio o leitor é de fato deixado livre para efetuar o seu percurso de leitura, por sinal correta, como afirma a Conclusão do autor (15), evitando histórias que possam não lhe interessar ou the parecer inconvenientes (com o resultado negativo, entende-se, de se colocar entre os leitores aqueles que não estão à altura do texto).

O Decameron tem o que hoje chamaríamos (não muito apropriadamente) um subtítulo, já que é "cognominado príncipe Galeotto" (e tal denominação repete-se na conclusão do livro). Não existe qualificação mais potencialmente enganosa do que esta, como de fato aconteceu geralmente nas práticas de leitura. Porque, aludindo às palavras de Francesca, "Foi Galeoto o livro, e o seu autor" (Inf., V, 137, p. 54), e à sua banalização, na verdade feita pelo próprio Boccaccio como comentador de Dante, poderia provocar um curto-circuito que o texto vice-versa não autoriza de forma alguma, e, antes, demonstra ser completamente errôneo. Estas as palavras de Boccaccio nas suas Exposições sobre a Comédia de Dante, a propósito do passo evocado:

E então esta mulher quer dizer que aquele livro que ela e Polo (sic) liam, sobre aquele encontro que Galeoto engendrou entre Lancelote e a rainha Genebra e que disse ter sido ele mesmo a escrever tal história; quer dizer que, se não a tivesse escrito, poderia não ter acontecido o que aconteceu. Nesse dia não o lemos mais adiante . Muito oportunamente mostra o que se seguiu, depois de ela ser beijada por Polo, e que os os leitores, sem que ela o diga, devem compreender. (PADOAN, 1965, V (1) 184, p. 324).

Paradoxalmente, pode-se dizer que a própria banalização efetuada por Boccaccio reforça o sentido da distância para a qual chamo a atenção. No início do Decameron (I Intr., 79), Boccaccio avisa que Panfilo, Filostrato e Dioneo, os três narradores masculinos, amam, respectivamente, três das sete narradoras (Pampinea, Fiammetta, Filomena, Emilia, Lauretta, Neifile, Elissa); mas, um rápido parêntese, que rompe a casca convencional das disputas dialéticas iniciais, registra que Neifile, no primeiro encontro com o trio de jovens, estava "com o rosto totalmente enrubescido pelo pudor, pois era uma das amadas dos jovens” (I Intr., 2013, p. 37). Ora bem,

13 Será utilizada, para as citações dos trechos de o Decameron, a tradução feita por Eugenio Mauro. ALIGHIERI, D. A Divina Comédia. São Paulo: Editora 34, 2004. Inferno, p. 119. 
são muitas as citações do texto que corroboram o filtro interposto por Boccaccio entre literatura e vida. Aqui basta somente, para esclarecer o que foi dito anteriormente sobre as estratégias do autor, quanto foi expresso por Panfilo (o narrador masculino ao qual parece confiada, por assim dizer, a posição de autoridade que entre as mulheres cabe a Pampinea), na conclusão da jornada por ele chefiada, não por acaso a décima, assim como a primeira é governada precisamente por Pampinea:

Como é de seu conhecimento, amanhã faz quinze dias que saímos de Florença para termos alguma distração que nos servisse de amparo à saúde e à vida, pondo fim a melancolias, dores e angústias a que assistimos sem cessar em nossa cidade desde que tiveram início esses tempos de peste; coisa que, segundo meu juízo, fizemos com honradez; pois, se eu tiver bem observado, embora tenham sido contadas histórias alegres e talvez capazes de despertar a concupiscência, embora tenhamos continuamente comido bem, bebido, tocado e cantado, coisas estas de índole a incitar as mentes frágeis a coisas menos decorosas ${ }^{14}$, não chegaram a meu conhecimento atos ou palavras, enfim, nada que fosse censurável, nem da parte das senhoras nem da nossa; contínuo decoro, contínua concórdia, contínua familiaridade fraterna: foi isso o que me pareceu ver e ouvir. E isso, sem dúvida, me agrada dizer para honra e mérito das senhoras e de mim. (X Concl., 2013, p. 621)

A insistência para que se fosse mantida a honestidade (termo-chave do livro, com seus derivados), a despeito de ocasiões que a poderiam ter facilmente derrubado (o que fazem somente as "mentes fracas", evidentemente inaptas para entender a lição do Decameron), não poderia resultar mais clara. ${ }^{15}$ Boccaccio, pela boca de Panfilo, comunica-nos que, durante todo o tempo de entretenimento dos jovens, narradores e narradoras da coletânea, e mais ainda aqueles já implicados em relações amorosas, não cometeram o erro dos amantes dantescos (que resultam assim ser uma espécie de declinação negativa, ou mimeticamente ingênua, das forças que agem no livro "chamado Decameron"): não foram, portanto, vítimas, como Francesca e Paolo, da indevida sobreposição entre literatura e vida (BATTAGLIA RICCI, 1987, p. 179-198). Com efeito, nunca nenhum rótulo foi excogitado com tanta sutileza e insídia como a usada por

14 O texto original de Boccaccio usa o termo "onesto" que admite vários significados e traduz a atitude reta, virtuosa e digna dos protagonistas-narradores em suas vidas, por isso, acreditamos a tradutora tenha escolhido o termo "decoro" que lhe pareceu abranger mais amplamente os sentidos do termo original (N.T.)

15 Sobre este ponto, cfr. a exaustiva resenha (do mundo antigo a Boccaccio e além dele) de Cherchi (2004). 
Boccaccio ao dar a qualificação de "Galeotto" ao seu livro; a responsabilidade pelo uso correto deve cair, por explícita tomada de posição de Boccaccio (conferida precisamente na Conclusão do autor), sem dúvida sobre o leitor. Explico-me: recorrendo à clássica distinção de Berlin (1998, p. 69-157) entre o ouriço e a raposa, pode-se dizer que se o primeiro faz convergir tudo para uma visão central, forçando assim o leitor ao consenso, a segunda, deixa-o livre, disseminando o próprio percurso com falsas pistas, e até desviando-o, obrigando-o penosamente, como o Pequeno Polegar, a encontrar sozinho o caminho certo (e essa é sem dúvida a posição de Boccaccio). ${ }^{16}$

Em um plano diferente, que invoca abertamente a alusividade intertextual, coloca-se a introdução da quarta jornada: um dos segmentos textuais que, recaindo sobre a exclusiva sentença autoral, e subtraindo-se, portanto, às intermediações dos narradores, implica um alto coeficiente de explicitação. Pois bem, também nessa parte fundamental do livro, o desafio com Dante é nitidamente perceptível e acentuado (e não menos problemático) por obra de específicas conexões textuais. Leiamos dois breves excertos, extraídos do início e de um trecho que se apresenta no fim da "autodefesa":

Caríssimas senhoras, tanto pelas palavras que ouvi dos sábios quanto pelas coisas que tantas vezes vivi e li, estimava eu que o impetuoso e ardente vento da inveja só açoitasse as torres altas ou os cimos mais elevados das árvores, mas vejo que fui enganado pela minha estimativa. Pois, sempre fugindo e empenhando-me em fugir do ímpeto feroz desse espírito raivoso, fiz questão de caminhar, silencioso e oculto, não só pelas planícies, como também pelos vales profundos. E isso se manifesta claramente a quem observar estas pequenas novelas, não só escritas em florentino vulgar, em prosa e sem título, como também no estilo mais humilde e baixo que posso. Nem por isso consegui deixar de ser violentamente sacudido por tal vento; aliás, fui quase desarraigado e totalmente dilacerado pelas mordidas da inveja. Por tais coisas posso compreender claramente a verdade do que costumam dizer os sábios, ou seja, que somente a miséria não desperta inveja neste mundo. (IV Intr., 2013, p. 237)

E, julgando que desta vez respondi o bastante, digo que, armado da ajuda de Deus e da sua, gentilíssimas senhoras (a qual espero), e de muita paciência, seguirei em frente, dando as costas a esse vento e deixando-o soprar; pois vejo

16 A distinção, que sumariamente retomei da bem diferentemente articulada formulação originária, in BERLIN $1998^{2}$ : 69-157. 
que comigo só poderá ocorrer o que ocorre com a poeira miúda quando o vento sopra em remoinho: ou ele não a move do chão ou, se a move, leva-a para o alto e frequentemente a deposita na cabeça dos homens, nas coroas de reis e imperadores e às vezes sobre os altos palácios e as excelsas torres; e de lá, se ela cair, não poderá ir para lugar mais baixo do que aquele de onde foi tirada. (idem, 2013, p. 241)

As referências dantescas (sobretudo a exortação de Cacciaguida, Par., XVII 133-35) como essas e outras presentes na introdução da quarta jornada foram todas ilustradas por Branca em seu comentário, de modo que não é necessário insistir nisso, se não para ressaltar que as mesmas têm naturalmente a função de exaltar, contra toda atitude oficiosa de modéstia, a própria obra. Vou me concentrar, por outro lado, em uma imagem recorrente e central dos trechos selecionados, aquela do vento, levantado pela inveja; porém não se deve esquecer que a inveja, no papel de agente, é veiculada também por meio das figuras da mordida e dos dentes, segundo uma trajetória que tem precedentes tanto veterotestamentários como clássicos. ${ }^{17}$ Quanto à figuralidade ligada ao vento, encontra-se enraizada na tradição bíblica (ressalto isso porque, diferentemente do que acontece para Dante e Petrarca, a mensagem passou por muito tempo despercebida nos estudos boccaccianos); ${ }^{18}$ seu uso está sobretudo ligado a três diferentes situações, duas das quais pressupõem a potência de Deus, que se pode manifestar: 1) ou negativamente, como manifestação de sua ira (Ex., X 13; Is., XVII 13; Jer., XVIII 17); 2) ou positivamente, na ajuda concedida aos Israelitas quando atravessaram o Mar Vermelho (Ex., XIV 21). Interessante notar nesse sentido que, no Novo Testamento, a presença de Cristo é frequentemente associada à calma das águas na ausência de vento, sendo também esse detalhe o resultado do novo pacto estabelecido por Deus com o homem (Mt., VIII 26, XIV 32; Mc., IV 39, VI 51; Lc., VIII 2425 , etc.); 3) a imagem vale porém só negativamente para designar a vaidade, quer em fatos quer em palavras, da vida humana (Job, VI 26, VII 7; Ecclesiastes, V 15, etc.). Tal uso é feito nomeadamente por Dante na depreciação da fama mundana que se lê nas palavras de Oderisi da Gubbio (Purg., XI 100-2). Cumpre notar que Boccaccio, nos excertos supra reportados, segue esse último canal figural, tachando, assim, de vaidade não tão somente a própria fama (que por sinal, seguindo o exemplo dantesco, também é marcada pela vaidade, segundo uma visão milenarística), como também a tentativa de diminuir o valor do Decameron. Comentando

17 Para as ocorrências veterotestamentárias, cfr. Job, XVI 10; Ps., XXXIV 16, XXXVI 12, e, sobretudo, LVI 5 , CXXIII 6, etc. Os precedentes clássicos referem-se sobretudo a Ovídio e Sêneca, já presentes em Fiammetta, V 19, IX 19; cfr. Delcorno 1994, p. 119-120, 188, p. 326 n. 40, p. 389 n. 48.

18 Cfr. Bragantini (2012, p. 69-87), que aqui em parte retomo e desenvolvo. Também esta fundamental frente está positivamente se abrindo: cfr. Battaglia Ricci (2013, p. 134-156), com indicação também de outros trabalhos em curso sobre o assunto. 
o segundo dos dois excertos selecionados (a propósito da ação do vento que, agindo na poeira a deposita "sobre os altos palácios e as excelsas das elevadas torres" - 2013, p.241), em sua glosa Branca (BOCCACCIO, 1980, p. 469) interpreta: “as calúnias [...] não podem rebaixar sua obra, mas provavelmente apenas sublimá-la”. A interpretação é correta, naturalmente, mas talvez se possa chegar mais perto do significado usado por Boccaccio. No primeiro passo selecionado, Boccaccio diz que se esforçou para percorrer os "profundíssimos vales", dado que o vento que se erguera pela inveja atingia, sobretudo, "as torres altas ou os cumes mais altos das árvores". Mas, retornando ao ponto, na conclusão da autodefesa, a imagem, que reformula talvez o Eccl., XII 7 ("et revertatur pulvis in terram suam unde erat" - "e o pó volte à terra, de onde veio"), de certa forma converte-se no seu contrário. Mas justamente a inconsistência que caracterizaria seu livro é que lhe pode garantir chegar em forma de pó (outra imagem evidente de vaidade) até às cabeças dos reis e dos imperadores. Portanto, a contestação inicial de ter evitado situar-se em zonas excessivamente rarefeitas, converte-se em seu contrário. Como a dizer que, tendo presente a passagem dantesca da qual provém a autodefesa, Boccaccio inverte o sentido da voz profética de Dante; melhor dizendo, alterando as relações inerentes ao significante, deixa intacto o significado. Boccaccio não é Dante, o vento de denúncia "que aos sumos cimos alça os lanhos seus" (Par., XVII, 134, 2004, p.126), mas é, sobretudo, inspirado por ele; todavia, a leveza de seu livro, como de sua pessoa, em que insistirá a Conclusão do autor (23), garante-lhe também suficiente liberdade para fazer sua crítica tanto contra os poderosos da terra quanto contra seus opositores.

Mencionei a pouca atenção que até há pouco tempo foi dada às repercussões bíblicas no Decameron. Digo repercussões porque falar de intertextualidade para o Velho e o Novo Testamento, em relação a um autor medieval, é usar um termo que não designa com clareza o tipo de relação que eu gostaria de ilustrar. Reporto aqui as palavras de padre Pozzi (1996, p. 150), usadas por Petrarca, mas perfeitamente apropriadas para Boccaccio (e, mais ainda, obviamente, para Dante):

Naquele tempo, como hoje, mas bem mais naquele tempo do que hoje, as presenças bíblicas não se resolvem; uma vez preparado o catálogo das citações, na perspectiva da passagem de texto a texto. A Bíblia era por um lado o livro (e não um livro, mesmo que maximamente respeitável), e por outro, agia fora da medida livresca, pois era também experiência. 
Feita essa consideração, é preciso especificar que tais ecos, no Decameron, não têm, o que é facilmente compreensível, o mesmo peso nem (e o que é mais importante) a mesma evidência que adquirem no Cancioneiro ou na Comédia. Se é fácil remontar, por explícita declaração do autor, a partir de uma sentença ("mesmo que venha a precisar, sei, como diz o Apóstolo, viver na penúria e na abundãncia"; IV Intr., 2013, p.241) à sua origem neotestamentária ("Scio et humiliari, scio et abundare, ubique et in omnibus institutus sum et satiari et esurire, et abundare et penuriam pati"; Ad Philipp., IV 12), ${ }^{19}$ menos fácil é identificar, na voz inaugural de Panfilo, na novela de Ser Ciappelletto ("Caríssimas senhoras, todas as coisas que o homem fizer, é conveniente que eles as principie com o santo nome d'Aquele que as fez todas"; I, 1, 2013, p.41 ), a mesma sentença paulina ("Omne quodcumque facitis in verbo aut in opere, omnia in nomine Domini Iesu, gratias agentes Deo et Patri per ipsum"; Ad Col., III 17). ${ }^{20} \mathrm{E}$, de fato, tal evidência dificilmente tem um lugar nos comentários, não aparecendo, salvo erro, nos modernos. Contudo, parece haver poucas dúvidas que, por força de sua posição no incipit na elaboração da narrativa, aquelas palavras estejam relacionadas com a sentença paulina, tão operante não só como exigência de suporte divino, mas como bom augúrio para o sucesso da empresa.

Insisto sobre a dificuldade de detectar no Decameron indícios intertextuais que remetam, mais ou menos explicitamente às Escrituras. Mas insisto também na necessidade de todo esforço para individuá-los, ampliando o discurso para o mais árduo dentre os comentários bíblicos, bem como dentre os escritos dos pais e doutos da Igreja, por meio da alegação de um único specimen. Transcrevo o passo de São Bernardo p. 315 c-d) - autor muito caro a Boccaccio -, tomado, por sua vez, das Lamentationes, III 27-28:

"ut in coelum ascendas, necesse est levare te super te, calcando carnalia desideria quae in te militant adversus te" (In ascensione Domini, Sermo IV, De duabus malis ascensionibus, daemonis et primi hominis: et sex bonis, Christi et nostris). ${ }^{21}$

Sugiro, com o benefício da dúvida, a possibilidade do trecho ser revisitado, com paródia mordaz e mudança de registro (passagem do sério ao cômico), na decisão de Alatiel, mulher de silenciosa desconfiança, de ceder aos galanteios de Pericone: “(...) concluiu que, com o correr do tempo, precisaria aquiescer por bem ou por mal às vontades de Pericón; assim, decidindo com grandeza de ânimo que venceria as misérias de seu destino (...)" (II,7, 2013, p. 122) . O transvasamento não pode ser definido como fluido, com exceção do uso de pisar (que é uma

19 Sei estar abatido, e sei também ter abundância; em toda a maneira, e em todas as coisas estou instruído, tanto a ter fartura, como a ter fome; tanto a ter abundância, como a padecer necessidade. Filipenses 4:12. In: www.bibliaonline.com.br

20 E tudo quanto fizerdes, por palavras ou por obras, fazei tudo em nome do Senhor Jesus, dando por ele graças a Deus Pai. Colossenses 3:17. In: www.bibliaonline.com.br

21 O passo in Patrologia Latina, vol. 183, p. 315c-d. "Para poderes ascender ao céu, é necessário que te eleves acima de ti, pisando os desejos carnais que em ti habitam e estão contra ti (Sobre a Ascensão do Senhor, Sermão IV: "Sobre duas más ascensões, do demônio e do primeiro homem; e sobre seis boas, de Cristo e nossas"). 
occorrência única no Decameron), que subverte a exortação de Bernardo, uma vez que o mesmo verbo usado por ele para vencer o desejo carnal é empregado em uma situação completamente antitética. Para o restante, Boccaccio adota os seguintes procedimentos: a) passagem da segunda à terceira pessoa que remete ao módulo bíblico, e recuperação e deslocamento ("pois se via sozinha, e sem ajuda nem apoio de ninguém" (II, 7, 2013, p. 124) da condição já explicitada de solidão e silêncio ("Sedebit solitarius et tacebit, quia levavit super se" - Lamentationes, III $28),{ }^{22}$ b) emprego, em relação a Bernardo, da forma nominal (levare te super te $>$ con altezza d'animo) para significar elevação e vitória sobre si mesmo, mas de modo invertido; c) eliminação da repetitio pronominal. O procedimento que se realiza aqui é exatamente o centão, porque extrai unidades reconhecíveis, adequando-as a um contexto radicalmente diferente em relação àquele de partida. Não se deve considerar estranha a memória, também neste caso subvertida, de Ovídio, Amores, III 11 5: "vicimus et domitum pedibus calcamus amorem". ${ }^{23}$ Deve-se assinalar ainda que o passo de São Bernardo recordado acima devia ser bem conhecido também de Petrarca se, neste caso, adotando plenamente as ideias do santo (isto é, permanecendo no âmbito do mesmo registro, do sério ao sério, deslocando somente a área de aplicação), o utiliza duas vezes, inclusive em conexão com outros sintagmas relacionados com a mesma área frequentada por Boccaccio (nos passos logo a seguir reportados, alto animo e "con altezza d'animo" são sobreponíveis). Na consolatória Familiaris VI 3 a Giovanni Colonna, é feito o seguinte convite:

meminisse laborum ac dolorum quos pro nobis Cristus pertulit [...]; meminisse clavorum ac lancee preciosissimique sanguinis, quo lavacro, sordibus ablutis, recreati et clementer admoniti sumus temporales alto animo calcare molestias, nichilque nisi eterne damnationis et penarum immortalium supplicia formidare. (PETRARCA, 2004-2009, II p. 828). ${ }^{24}$

Em outra carta consolatória, la Familiaris XVI 6 (esta dedicada ao bispo Nicolò da Viterbo), lê-se: "Hinc iam virilter admonendum es, ut memineris per te ipsum mortalia ferre alto animo atque despicere, calcare presentia, sperare meliora [...]" (PETRARCA, 2004-2009, IV p. $2250) .^{25}$

22 “Assente-se solitário e fique em silêncio; porquanto Deus o pôs sobre ele.” Lamentações 3:28. www.bibliaonline. com.br

23 "Venci e pisoteei sob os pés o Amor domado."

24 "Lembrar-se dos afãs e das dores que Cristo suportou por nós [...]; lembrar-se dos pregos e da lança e do preciosíssimo sangue, cujo martírio cancelou as nossas máculas e nos renovou e de modo benevolente nos alertou a conculcar com ânimo nobre as moléstias temporais e nada mais temer, a não ser os tormentos de uma danação eterna e de penas sem fim.” Datada Valchiusa, 30 de maio, o ano estabelecido para essa epístola é 1342.

25 "Mas agora devo virilmente admoestar-te a suportares com ânimo nobre e a desprezares as coisas terrenas, a não te preocupares com o presente, a esperares o melhor [...].” A carta não é datada, mas a primeira consistente redação autógrafa transmitida pelo códice dos esboços reporta a data de 15 de fevereiro de 1353 e a cópia na coletânea está colocada logo a seguir. (cfr. PETRARCA, 2000, p.112-114). 
Os trechos citados até aqui devem ser inseridos, naturalmente, em uma discussão mais densa e documentada o melhor possível, para verificar se o centão de Boccaccio, no trecho em questão, não assimile, como acredito ser possível, também o Petrarca das epístolas do Familiares citado acima (ao menos aquele do primeiro exemplo, já que o segundo é muito próximo às datas hipotizadas para a composição do Decameron $) ;{ }^{26}$ pode-se, no entanto, asseverar que a formulação usada por Boccaccio ("decidindo com grandeza de ânimo que venceria [pisotearia] ${ }^{27}$ a miséria de seu destino" - 2013,p.122), que para nós hoje pode parecer ligada por fios muito tênues à reelaboração que São Bernardo realizou sobre a escrita de Jeremias, muito provavelmente terá sido melhor compreendida com toda sua carga alusiva pelos primeiros leitores do Decameron (e, pode-se entender, mais maliciosos) que seriam também, talvez, leitores de Petrarca. De tudo isso se poderia deduzir um pequeno, mas não irrelevante esclarecimento hermenêutico: caso o passo boccacciano se evidenciasse como um exercício efetivo e com caráter de centão sobre os escritos de Jeremias, Lamentações, e São Bernardo, via Petrarca, teríamos a confirmação definitiva que em seu texto pisar tem o sentido de "pisotear" (incontestável, na minha opinião), mais do que, como foi considerado possível, "percorrer toda infelicidade de suas [de Alatiel] desditosas condições".

Outra questão relativa aos modelos que só recentemente foi corretamente considerada, principalmente por mérito do lamento fúnebre de Giuseppe Velli, é aquele dos clássicos. Trata-se de um fato sobre o qual é necessário delongar-se, porque a qualificação de livro de entretenimento conferida muito apressadamente ao Decameron colocou a questão sob uma perspectiva deturpada. A ênfase sobre a contemporaneidade dos eventos e dos protagonistas (como se estes não o fossem também na Comédia, que com os clássicos está em diálogo contínuo) induziu a se negligenciar o fato de que também Boccaccio, quando interpreta as ocorrências e os personagens coevos, o faz insistentemente com o auxílio dos clássicos latinos. Apesar disso, tal fato parece não ser ainda senso comum (e, de fato, faltam quase sempre vestígios ou comentários sobre isso). Mas como interpretar o desdenhoso gracejo de Guido Cavalcanti ao grupo de jovens ociosos que tenta em vão assediá-lo ("- Senhores, em sua casa podem me dizer o que quiserem. (VI, 9, 2013, p. 372), a não ser remetendo-nos à sentença

26 Sobre algumas trajetórias Petrarca-Boccaccio cfr. Velli (1995,p. 237-243), que indica indícios petrarquistas também na descrição inicial da peste (Epystole metrice, I 14, Ad se ipsum), e em alguns passos da novela de Ghismonda (Africa, V 720-34). 
de Sêneca "otium sine litteris mors est et hominis vivi sepultura"27 (Epistulae ad Lucilium, X $823) .{ }^{28} \mathrm{~A}$ falta de registros nos comentários atuais surpreende ainda mais se pensarmos que as epístolas de Sêneca, obviamente bem conhecidas por Boccaccio, são objeto de uma atenta seleção antológica no Zibaldone Magliabechiano autógrafo. Não deve constituir impedimento o fato de que tal seleção tenha apenas os primeiros seis livros, porque se deve considerar que na preparação do Zibaldone ele ainda não possuía o códice de Sêneca assinalado no catálogo "parva libraria" (COSTANTINI, 1974).

Com a resposta de Guido, estamos ainda em território relativamente confortável. Contudo, as coisas ficam mais difíceis quando Boccaccio, que é um admirável deturpador de gêneros e percursos narrativos destoantes, decide basear-se em modelos que não se supõe possam encontrar-se por trás do seu exercício literário. Tomemos como exemplo (trata-se ainda de uma trouvaille de Velli) a novela de Bernabò e Zinevra. A genial introdução mercantil desnorteou os leitores, impedindo-os de entender que o motivo inicial é tomado da narrativa do episódio que se segue ao jantar dos filhos do rei Tarquinio. De fato, "certa noite, depois de terem [os 'mercadores'] todos jantado alegremente, começaram a conversar sobre diferentes coisas e, passando de um assunto a outro, acabaram falando de suas mulheres, que tinham deixado em casa. (II,9, 2013, pp. 146-7), remete precisamente a "Forte potantibus his apud Sex. Tarquinium [...] incidit de uxoribus mentio"29 (Livio, Ab urbe condita, I 57 6) (VELLI, 1995, p. 233-234). Depois disso a narração segue o seu caminho, não sem outros aportes bíblicos, uma vez que os louvores tributados por Bernabò à sua mulher são tramados, como demonstrei anteriormente, a partir do elogio da mulier fortis que encerra os Proverbia (XXXI 10-31) (BRAGANTINI, 2012, p. 72). Mas ter ignorado, até as investigações de Velli, o precedente liviano (e continuar a ignorálo, em muitos casos), sem dúvida empobreceu o exercício narrativo, e tirou muito da substância antropológica de Zinevra (assim como sua essência bíblica e clássica, em perfeito paralelismo com Dante e Petrarca); além de, acrescento, não ter fornecido a medida da mediocridade da figura de Bernabò que, desde o implícito confronto com Collatino, amesquinha-se ulteriormente, por ter apostado dinheiro em uma figura definida por ele mesmo como inigualável. Sem dúvida, a dificuldade em perceber o precedente liviano deriva não somente da decisão boccacciana de reorientar em âmbito mercantil um dos mais célebres episódios da antiga história de Roma, com êxito muito feliz da narração, mas também da lição decisiva que aqui se oculta, em relação à reescrita boccacciana. Na verdade, ela não se limita a repercorrer precedentes textuais (dos quais, inclusive, se aproveita de poucas linhas e cancela quase sistematicamente os rastros),

27 "O ócio não nutrido pelos estudos equivale à morte, a ser sepultado vivo."

28 Cfr. Velli (1991, 1995). Diferente a sequência identificada em Quondam, Fiorilla e Alfano (BOCCACCIO, 2013, part. p.970-971); mas a explicação do mote oferecida por Betto Brunelleschi indica como determinante sobretudo o filtro de Sêneca.

29 Certa vez, enquanto estavam bebendo na tenda de Sexto Tarquínio [...] o discurso recaiu sobre as mulheres. 
submetendo, porém, a uma nova leitura os argumentos intelectuais ou morais.

Torna-se útil aqui propor um princípio geral que o estudo do tratamento das fontes em Boccaccio sugere, e não apenas pelas razões pertinentes à fisionomia do livro: contrariamente ao que acontece com o Dante da Comédia, no qual o conjunto e o singular compenetram-se e correspondem com evidência plena e recíproca, com Boccaccio (e em boa parte o mesmo pode ser dito sobre o Petrarca do Cancioneiro) a lei que governa o todo só pode ser obtida a partir da inteligência do funcionamento do singular.

Para dar evidência desse fato, detenho-me em algumas novelas da segunda jornada. Começemos pelo provérbio que encerra a notória novela de Alatiel: "Boca beijada não perde ventura; antes, renova como faz a lua" (II,7, 2013, p. 134). ${ }^{30} \mathrm{O}$ dito proverbial contradiz literalmente o preâmbulo de Panfilo ("gostaria de lhes contar uma história sobre a desventurada beleza de uma sarracena” (II,7, 2013, p. 119); mas todo o segmento introdutório é, na verdade, uma exposição en raccourci da décima sátira de Juvenal, preenchida de sentenças morais dentre as mais conhecidas da latinidade, e submetida a uma leitura dissimulada em uma perspectiva de sensualidade transgressora, paralela e convergente com a metódica inversão do esquema do romance alexandrino. ${ }^{31}$ Nesse caso, parece difícil individuar se nasceu primeiro o ovo ou a galinha, isto é, se o provérbio conclusivo tenha agido como impulso inicial, ou se é a glosa escarnecedora final do indubitável motivo juvenalesco. No primeiro caso, se deveria pensar em um movimento de expansão ao redor do núcleo proverbial, no segundo, em uma reelaboração de um outro tipo que mira a reescrita das sentenças detectáveis em Juvenal e termina por desmentilas. Talvez fosse mais correto pensar em um movimento alternado de sístole (reescrita de Juvenal, pela seleção, compressão, deslocamento) e diástole (expansão da motivação proverbial, que desmente a fonte). Ampliando o panorama talvez seja possível lançar um olhar mais articulado não somente sobre a oficina literária de Boccaccio, mas também sobre seu modo de proceder em casos análogos. Sabe-se como sua requintada prática de parodista lhe sugere o deslocamento de sequências que têm uma fonte comum, e enfim como ele distribua em partes diferentes do livro um mesmo motivo, variando suas componentes - o procedimento foi ilustrado com particular acuidade por Forni (1992, 2008, p. 27-40). Uma lição que se pode tirar da prática do comentário em primeira pessoa ou que se poderia, grosso modo, formular nos seguintes termos: quanto menos astuto e culto é o autor a ser comentado, mais fácil se faz o caminho, uma vez que o centro de irradiação das fontes tenha sido individuado, porque daquele centro partem geralmente também os percursos laterais. No caso oposto, o de um autor culto e hábil em dissimular os

30 Para a função do provérbio na narrativa dos primeiros séculos, cfr. Bragantini (2014). 31 Para os dois aspectos, cfr. respect. Velli (1995, p. 244-247) e Segre (1974). 
rastros, a situação se faz antitética: ter encontrado uma fonte segura não pode oferecer nenhuma garantia, não só porque tal fonte não é exclusiva, mas também porque não se pode dizer que não vai saltar de novo para fora, quando menos se espera.

Voltando à décima sátira de Juvenal, vemos que ela se concentra nos pedidos absurdos que os homens fazem aos deuses, rogando-lhes para obter riqueza, poder, beleza, que são todos e sempre fontes de desditas. Seria melhor pedir, escreve Juvenal, nada mais que mente e corpo sãos. A exortação que fecha a sátira é ainda mais explícita: "[...] semita certe / tranquillae per virtutem patet unica vitae. / Nullum numen habes, si sit prudentia: nos te, / nos facimus, Fortuna, deam caeloque locamus" (363-66). ${ }^{32}$ A didascália geral da segunda jornada prescreve que se conte "sobre quem, apesar de atribulados por diferentes coisas, chegam a um final feliz" (I, concl., 2013, p.74): mas a rainha Filomena, precedentemente, tinha evocado, mais explicitamente a sorte (I Concl., 10). Se a novela de Alatiel mostra ecos evidentes do texto de Juvenal e, se nele a sorte tem peso dominante, é lícito perguntarmo-nos se Boccaccio, seguindo um de seus expedientes típicos, não teria criado, por esporogênese, outras unidades narrativas originadas daquele núcleo.

Aproveitando a excelente análise de Velli a propósito da reutilização de Juvenal na novela de Alatiel, pode-se sugerir que uma porção do mesmo texto, ou melhor uma sua motivação, seja também detectável por trás da novela de Rinaldo d'Asti, isto é de uma história, observe-se, da mesma jornada (II, 2). Entende-se que a base seja oferecida pela popularidade da lenda de São Julião, anotada também por Boccaccio no seu Zibaldone Magliabechiano, como recorda Branca (BOCCACCIO, 1980, p. 141-142) em seu comentário; mas o entreleçar-se de motivos diferentes e de fontes não só remotas entre si, mas díspares (uma ligada às práticas devocionais, outra aos clássicos) é praxis costumeira do autor. Pode-se afirmar que se o veículo é oferecido por aquela lenda, o motor tem de ser buscado em outra parte, visto que o tema da jornada é fornecido pelas reviravoltas da sorte, e pela possibilidade de se obter inesperados successos onde ela falta. E, com efeito, Rinaldo, roubado pelos três bandoleiros que levam seu dinheiro, suas roupas e seu cavalo, abandonado por seu servo, morreria de frio se não fosse reconfortado completamente pela bela viúva que lhe oferece banho quente, roupas, jantar e companhia amorosa. E não é só isso, pois ao despedir-se, a mulher lhe "enche a bolsa de dinheiro", de modo que, ao final da história, tendo recuperado tudo que lhe foi roubado ("não perdeu nada mais que um par de ligas" (II, 2, 2013, p. 88), teve aumentado o montante de dinheiro que lhe fora tirado. Na sua nota, Branca (BOCCACCIO, 1980, p. 15do 1) observa "o caráter absolutamente extraordinário (até demais)" dos acontecimentos. A excepcionalidade poderia ser aqui não uma supressão ao

32 "Só um caminho se abre para uma vida tranquila: o da virtude. Se reinar a sabedoria, não terás outro nume. Nós, só nós, Fortuna, fazemos-te deusa e colocamos-te no céu." 
verossímil decameroniano, mas originada pelo fato de que na base da narrativa, mais do que um episódio extraordinário, há talvez ainda a inversão da máxima da décima sátira de Juvenal, com aquele exagero excessivo que se transfere da fonte ao seu reúso. Falando da futilidade dos desejos de riqueza, Juvenal escreve: "Nocte iter ingressus, gladium contumque timebis / et mota ad lunam trepidabis harundins umbra: / cantabit vacuus coram latrone viator" (X 20-22). ${ }^{33}$ Pois bem, Rinaldo despreza exatamente aqueles avisos (leva consigo o dinheiro vivo, continua a viagem à noite, se faz acompanhar por estranhos) e, apesar disso, vence em todas as frentes (até econômicas). Se não estivesse próxima à novela de Alatiel, a certeza de sua derivação juvenalesca pediria maior cautela; mas a contiguidade sugere que as narrativas sejam parte de um sistema, costituindo um díptico sobre a boa sorte "além da própria esperança". Assim como cada trágico desaparecimento dos seus amantes apresenta-se para Alatiel uma aventura erótica diferente, de igual modo todas as perdas de Rinaldo transformam-se em novos e inesperados ganhos. De qualquer maneira, mesmo que fosse assim, como é aparentemente possível, seria muito difícil individuar a genealogia da sequência de eventos desagradáveis que levou à dupla de narrativas analisadas. E seria ainda mais dificil entender se, quando averiguada a fonte comum, fosse possível considerar uma contemporaneidade criativa entre as histórias; isto é, se o desenho do livro se desenvolva juntamente com as novelas ou seja determinado em um momento posterior, ao se organizar a ordem de apresentação do material. ${ }^{34}$ Entretanto, pode-se considerar verossímil o fato de que tenham sido produzidas em sequência (como confirma ainda o processo de inversão comum às duas novelas), assim que foi determinado o tema da jornada; e acrescente-se que os dois protagonistas correspondem plenamente ao cliché pertinente aos dois sexos (o desejo de ganho para o homem e o de beleza para a mulher; na verdade, Juvenal tem em mira igualmente a beleza masculina, com os exemplos de Hipólito e Belafronte). Mas de acordo com qual processo mental se deu a inversão é difícil dizer, porque enfrentamos os mecanismos da memória de um autor, como Boccaccio, que tem plena familariedade com seus textos, com aparatos mentais impossíveis de serem descritos. Em outras palavras, se Boccaccio condensa em poucos parágrafos da novela de Alatiel porções textuais consistentes com a décima sátira de Juvenal, por qual motivo, no caso da novela de Rinaldo d'Asti, não age de forma tão evidente, já que é possível identificar nela um revérbero, mas não os contatos indiscutíveis com o texto latino? Uma resposta poderia vir daquilo que infelizmente nos falta, isto é, o conhecimento do processo elaborativo do texto boccacciano (o que, por outro lado, é consentido no caso do Cancioneiro de Petrarca). A lógica diria que neste caso deve-se levantar a hipótese de uma

33 "Se te puseres em viagem de noite, deverás temer paus e espadas, e assim morrer de medo pela sombra de uma vara que balança ao lampejar da lua. O viajante de bolso vazio passará cantando diante de um ladrão."

34 A tentativa em larga escala de Padoan (1978) parece muito complicada. 
primogenitura ligada ao texto que traz elementos verbais com certezas verificáveis, apesar de serem manejados com tamanha habilidade que passaram inadvertidos por séculos (neste caso, a novela de Alatiel), dos quais depois teriam surgido satélites menores; o que explicaria também o desaparecimento dos traços textualmente mais salientes nessas últimas narrativas, o que ocorreu não tanto para tornar menos clara a derivação, mas pela mera inserção de formas da fonte primária feitas de memória. Com as palavras de um mestre de estudos sobre Dante, válidas também, nessa perpectiva, para Boccaccio, pode-se dizer que a aproximação a este último, a “Quellenforschung (estudo das fontes) deve inevitavelmente permanecer elusiva, pelo menos em parte: a sua era uma mente para a qual toda assimilação representava instintivamente o início de uma alquimia" (DRONKE, 1990, p. 14). Que os compostos que a alquimia produzem sejam parcialmente diferentes para Boccaccio, isso não altera a substância da coisa.

O discurso pode ainda ser expandido para outra novela da segunda jornada, aquela de Landolfo Rufolo, apresentado como aquele que "não satisfeito com sua riqueza, desejando duplicá-la, por pouco não a perdeu por inteiro, com a própria vida." (II, 4, 2013, p. 95). Nesse caso, não se trata, portanto, de desejo de riqueza, mas da avidez. A condenação da ambição é um ponto comum, tanto nos pronunciamentos paulinos (I Ad Tim., VI 9-10) como nas execrações dantescas e petrarquistas, de modo que nada indicaria que esteja ligada a Juvenal. Não se trata sequer da primeira vez que Boccaccio toca no tema, já enfrentado na obra juvenil, Filocolo (V 92 9), como nos recorda Branca (BOCCACCIO, 1980, p. 167-168) em seu comentário. Contudo, uma exortação para ficar longe da cobiça, Boccaccio encontra-a pronta e perfeita, por acaso, na mesma sátira de Juvenal supracitada. Mas, repito, encontra-a por associação espontânea da memória, não por ter lançado mão do recurso livresco: "sed pluris nimia congesta pecunia cura / strangulat et cuncta exuperans patrimonia census / quanto delphinis Ballaena britannica maior" (12-14) [...]. ${ }^{35}$ Pode-se considerar mais do que provável que esse motivo inicial seja o mesmo. Estaríamos, então, na presença de um trítico juvenalesco no âmbito da mesma jornada. Poderíamos deduzir que se tenha produzido um "efeito cascata", desse modo, o encobrimento dos traços reconhecíveis nas duas últimas narrativas não seria fruto de uma estratégia preventiva e calculada; seria mais o êxito devido a uma total familiaridade com o texto base que oferece por si só, uma vez estabelecido o tema da jornada, as passagens fundamentais, através das quais se pode verificar o peso da sorte nas aventuras humanas. Em outras palavras, a memória textual apurada no caso da novela de Alatiel, acionou a memória associativa, dando origem às novelas de Rinaldo d'Asti e de Landolfo Rufolo.

35 "Mas ainda mais sufoca o dinheiro amassado com demasiada avidez e um patrimônio que ultrapassa todos os outros, quanto a baleia britânica comparada a um golfinho." 
No entanto, para a demonstração de quanto o reconhecimento das fontes, e mais ainda a análise de como foram usadas, seja um dos pontos nevrálgicos não só para entender o modo de trabalhar de Boccaccio, mas para entender a ambição intelectual que conforma o texto de entretenimento por exelência da literatura, e não somente a italiana. Todavia, não consigo me persuadir de excluir, para a novela de Landolfo Rufolo, o aporte de outro texto: em suas Vite dei filosofi (Vidas e doutrinas dos filósofos ilustres), Diógenes Laércio registra, entre os dicta memorabilia de Antístenes, aquele que faz o elogio à autossuficiência e ao desprezo das posses; quem viaja deveria levar consigo provisões que, flutuando na água, pudessem sobreviver a um naufrágio juntamente com ele (VI 6). A afinidade com o enredo decameroniano, evidenciada exatamente pela inversão da situação parece reveladora (o ávido Landolfo preferiria morrer do que voltar para casa na miséria, e salva-se agarrando-se a uma caixa que flutua na água e que procura todavia afastá-la de si, antes de agarrá-la desesperadamente). Boccaccio não podia conhecer o texto grego das Vidas, pelo seu notório desconhecimento da matéria, nem podia ter acesso à versão latina completa, visto que a primeira a ser feita data de 1433 , por obra de Ambrogio Traversari (a chamada, versio Ambrosiana), (DORANDI, 2009, p. 222-228, part. p. 223-224). Além do mais, aquela máxima não parece ser detectada no repertório dos autores que são fontes habituais de Boccaccio (Cícero, Sêneca, Valério Máximo, etc.). Entretanto, não se pode excluir totalmente que ele conhecesse parte do texto, através de alguma antologia tardolatina ou medieval que tenha consultado; saliente-se que a máxima citada acima é considerada por alguns como obra de Aristipo de Cirene, outro autor que poderia ser evocado na discussão; para citar apenas dois títulos (mas vários outros poderiam se adequar ao tema), o Liber de vita et moribus philosophorum atribuído por muito tempo a Walter Burley (que se baseia largamente em Diógenes Laércio, citado constantemente, na sua compilação); $;^{36}$ ou o Compendiloquium de vita et dictis illustrium philosophorum de João de Gales - cujo manuscrito Riccardiano 1230, esteve em possesso de Boccaccio, que escreve apenas um comentário: notável (CURSI; FIORILLA, 2013, p. 54, n. 7).

Só parcialmente reelaborado em relação a Diógenes Laércio e enriquecido por detalhes narrativos, a máxima de Antístenes, atribuída a Aristipo (o mesmo nome do personagem que doutrina Gisippo e Tito: X, 8 6), encontra-se no trecho seguinte do Liber de Burley, ou melhor do pseudo-Burley (observe-se que a máxima final é precedida por uma tempestade que assusta o filósofo e por um naufrágio que o deixa em uma praia desconhecida):

36 Para Diogene Laerzio como fonte (juntamente com outros autores) de Burley, cfr. Knust (1964, p. 400-405) e Dorandi (2009, p. 201-212). A indicação de Burley como fonte filosófica boccacciana em Padoan (BOCCACCIO, 1965, p. 783 n. 103, p. 843 n. 380 e 382). A atribuição do texto a um anônimo autor setentrional da primeira metade do século XIV é defendida por Grignaschi (1990); alguma cautela a respeito em Petoletti (2000, p. 35-36). 
Navigante vero eo quandoque Corinthum et tempestate facta, nausiam passus est et expavit. Garrulus autem huic, tranquillitate reddita, dixit: "Quid est hoc quod nos quidem idiote intrepidi sumus, vos autem philosophi trepidatis?" Respondit: "Quia non de simili anima studemus. Te etenim pro nequissimi nebulonis anima nequaquam decuit esse solicitum, ego vere obnoxius debui de philosophi morte dolere, nam et homines divites amplius fures metuunt quam inopes". [...] Vitruvius vero in libro de architectura sic dicit: Aristippus, philosophus, Socratis discipulus, naufragio eiectus cum ad rodinense litus animadvertisset geometrica scemata descripta exclamavit ad comites: "Non desperemus, hominum quidem vestigia ego video". Statimque in oppidum rodinense conscendit et in gimnasium devenit ibique de philosophia disputans tantis muneribus ditatus est ut non tantum se ornaret, sed eciam eis qui cum eo erant et vestitum et cetera que opus essent ad victum praestaret. Cum autem eius comites reverti in patriam voluissent interrogarentque eum quid vellet domi renunciari, ita mandavit dici atheniensibus: eas possesiones et viatica liberis oportere parari que eciam e naufragio una possent enatare cum salvatis, et ea vera vite presidia estimarent quibus neque fortune tempestas iniqua unquam neque publicarum rerum mutacio neque privatarum rerum vastacio nocere potest. (KNUST, 1964, p. 148) ${ }^{37}$

Percebe-se que nem tudo flui com perfeito paralelismo na forma reproposta e parodicamente subvertida das máximas de Aristipo. Mas tanto a peculiaridade da recomendação final, situada, por isso, em uma zona de fácil memorização ("eas possesiones [...] possent enatare"; não acontece a qualquer um, como ao mercardor boccacciano, que vê os próprios bens literalmente flutuando consigo na água), quanto a advertência sobre as mudanças da sorte e da perda dos bens privados, são sinais que devem ser considerados, pois a caixa que salva a vida a Landolfo está cheia de jóias que duplicam a riqueza inicial do protagonista. O que aproxima esta história aos muitos casos examinados até aqui, é o tratamento asseverativo (VI, 9) ou antifrástico (II,

37 Enquanto navegava para Corinto, ergueu-se uma tempestade, sentiu náusea e teve medo. Retornada a calmaria, um deles, muito falador, disse: "Então o que é isso, nós, pessoas comuns, temos coragem e vós, filosofos, tendes medo?" Ao que ele respondeu: "Porque nós não nos ocupamos com o mesmo tipo de alma. Não sentiste a necessidade de te preocupares pela alma de um miserável, já eu senti a necessidade de sofrer pela morte de um filósofo, assim como os ricos temem os ladrões mais do que os pobres [...]". Vitrúvio no livro De architectura escreve o seguinte: "Aristipo, filósofo, discípulo de Sócrates, sobrevivido a um naufrágio e arremessado a uma praia de Rodes, tendo notado na areia figuras em forma geométrica, disse aos companheiros: 'Não nos desesperemos, vejo indubitáveis sinais humanos'. Subiu imediatamente para a cidade de Rodes e foi ao ginásio; aqui, discutindo de filosofia, enriqueceu com bens tão numerosos que conseguiu não só e adequadamente vestir a si mesmo, mas também dar de vestir e comer a seus companheiros. Estes, querendo retornar à pátria, perguntaram-lhe por que ele se recusava a querer regressar, ao que ele ordenou que dissessem aos atenienses o seguinte: que para os homens livres, basta munirem-se somente de bens e provisões de viagem que nem com os naufrágios se possam perder; e que considerem como verdadeiras defesas da vida aquelas que nem a tempestade iníqua da fortuna, nem a mudança das condições políticas, nem o saque das riquezas privadas possam alguma vez lesar." 
7), da máxima dedutível do repertório da antiguidade clássica, fragmentada em segmentos doxográficos o apoftegmáticos e situada no ponto de reviravolta da narrativa.

O que foi dito até aqui não deve surpreender, se pensarmos no valor central que a reflexão sobre a sorte assume na décima sátira de Juvenal; sorte que é o objeto exclusivo de toda a segunda jornada decameroniana. De preferência, devemos nos interrogar sobre a direção tomada da reescrita de Boccaccio que submete as situações observadas a escrutínio crítico e, por vezes, desmente ou declara explicitamente a sua fonte. Já se tratou de Alatiel, no esteio da análise de Velli. Mas deve-se prosseguir a análise com maior minúcia para as duas outras novelas analisadas. Seria possível dizer, nesse caso, que Boccaccio não queira subestimar de modo algum o papel da sorte, coisa que o Decameron a cada passo ensina (com maior evidência na premissa programática de Pampinea dentro dessa jornada; II 3 4-5); mas que, ao mesmo tempo, advirta contra qualquer atitude fatalista em relação a ela. Exatamente devido a seu caráter imprevisível, não necessariamente se deve considerar exclusivamente seu lado severo, pois cada revés da sorte pode se converter no seu contrário. Tudo se resume em saber tirar a lição destinada a cada um; com efeito, Landolfo Rufolo, protótipo, junto a Salabaetto, do mercador decameroniano desiludido com sua atividade (haverá ainda sentido falar da epopeia dos mercadores?), renuncia a exercitar futuramente o comércio e a tentar ulteriormente a sorte. Se o que proponho em relação a esta constelação de narrativas tiver fundamento, se poderia deduzir a validade do que foi antecipado acima: a necessidade de partir do particular para captar o sentido da operação no seu conjunto.

O fato é que ao sentido da operação nos aproximamos ainda com inércia mental, sobretudo em relação ao tratamento das fontes, mirando sobretudo a coisa, enquanto a fórmula melhor deveria visar o como (considerando a elaboração nos diversos níveis como visto acima. Para esclarecer esse ponto, acrescento ainda um último caso, a novela de Pietro Boccamazza e Agnolella (V, 3). O enredo, mais do que as narrativas greco-bizantinas, parece comparável aos romances de cavalaria medievais. Contudo, podem-se indicar outros e mais sutis pontos de contato. A quinta jornada reescreve positivamente muitas narrações funestas da jornada precedente, em particular, da história inicial que termina com a sepultura conjunta dos dois amantes (conclusão comum a outros episódios dessa jornada: 7, 8, 9). O rito, mais do que a marca da narração de Tristão e Isolda (como se lê frequentemente), remete ao caso de Piramo e Tisbe, ao qual a lenda medieval também está ligada. ${ }^{38}$ Mas Boccaccio realiza uma obra sistemática de carnavalização do mitológico e do sacro, em contínua atualização das experiências clássicas, e

38 Para as referências ovidianas que permeiam a obra de Boccaccio, cfr. Filosa (2012, p. 92-98, 109-111). 
numa reescrita camaleônica de episódios escriturais e patrísticos, ou da literatura monástica. ${ }^{39}$ Pietro e Agnolella são heróis históricamente plausíveis da Roma dos primeiros anos do século XIV e a conclusão de sua aventura é ditosa, mas alguns particulares do enredo têm como pano de fundo, embora velado, a história ovidiana. A oposição da família de Pietro e a investida noturna são fatos tópicos, mas outros detalhes assumem relevância distinta. Sigamos os passos sucessivos:

A jovem, vendo que a hora ia adiantada, ainda que as palavras do velho [o dono da casinha na qual se refugiava Agnolella] a assustassem, disse:- Deus há de querer nos proteger desse aborrecimento [de ser assaltados por bandidos, com "desgosto e vergonha" da moça]; e, mesmo que isso me acontecesse, é menos ruim ser maltratada por homens do que despedaçada por feras na floresta. (2013, p. 313)

[...] aconteceu que um deles [um dos bandidos que entram na casa do casal de idosos que protege Agnolella], não sabendo o que fazer, atirou sua lança ao feno e por pouco não matou a moça escondida e quando ela apareceu a lança foi dar ao lado da mama esquerda, a ponto de o ferro lhe rasgar a roupa, de modo que ela quase soltou um grande grito, temendo ser ferida; mas, lembrando-se de onde estava, recobrou-se e ficou quieta. (2013, pp. 313-4)

Os dois trechos sugerem que se trate de uma evocação do episódio dos dois amantes babilônios. Mas é a memória do leitor que fica em dificuldade, porque deve quanto possível procurar aproximar-se da memória ativa do autor, que joga as próprias cartas também nos segmentos que passam inobservados, enquanto o leitor tende a avançar por inércia, confiando nas operações automáticas, ao invés daquelas controladas pela reflexão sobre o fato específico (no caso, a sempre imprevisível reelaboração boccacciana da fonte). ${ }^{40}$ Tisbe, como se sabe, não é dilacerada pela leoa que mata a sede na fonte, depois de ter massacrado um armento (Ovidio, Met., IV 96-98), e é justamente o equívoco em que cai Piramo, ao chegar, a deflagrar a tragédia dos dois jovens; mas é exatamente este, e não por acaso, o temor de Agnolella. A demora específica, no segundo passo, é fruto da atenção descritiva minuciosa de Boccaccio, mas é preciso prestar atenção exatamente à gratuidade do gesto do bandido, cuja função é percebida

39 Para esses últimos aspectos, cfr. ao menos Delcorno (1995) e o recente Paciucci (2010).

40 Para o peso que sistema intuitivo continua a ter em relação ao reflexivo, cfr. Kahneman (2011). 
plenamente se tivermos presentes os versos ovidianos que seguem aqueles do aparecimento da fera: "ut lea saeva sitim multa conpescuit unda, / dum redit in silvas, inventos forte sine ipsa / ore cruentato tenues laniavit amictus"41 (ivi, 102-4). Uma sutura entre os dois trechos mostra como o episódio de Piramo e Tisbe se configure como pano de fundo, potencialmente mortal, do caso feliz de Pietro e Agnolella, cuja veste despedaçada é uma espécie de farrapo em forma de metonímia, um presságio de morte que não se realiza. Que a história tenha um final feliz, é apenas uma das inúmeras inversões que Boccaccio realiza. Por outro lado, se percebemos, justamente, um fundo dantesco na figura da jovem que "penetrou tanto na floresta que já não conseguia enxergar o lugar onde entrara" (2013, p. 312: com passo que, além do Purg., XXVIII 22-24, remete a Inf., XV 13-15), o mesmo esforço deve ser feito para se individuar, na complexa textura da novela, outras inserções; tendo presente preliminarmente que elas não se apresentam todas com o mesmo nível de variação e, em segundo lugar que, assim como Dante se vê sujeito a uma maciça pressão que tire seu catáter alegórico, do mesmo modo o texto de Ovídio sofre uma deformação que torna difícil individuar a sua presença, ainda mais diante de uma solução favorável (como acontece com a novela de Bernabò e Zinevra). Observam-se, enfim, mais uma vez aquelas formas de ligação às avessas indagadas por Forni que ilustra a proximidade de elementos figurais que encabeçam os enredos de êxito oposto ao original - nesse caso específico, o discurso de Forni (2008, part. p. 33-37) toca a imagem do coração arrancado que liga duas histórias de efeito antitético, trágico na novela de Ghismonda e comicamente feliz naquela de Ricciardo e Caterina (IV 1 46, V 4 42). A única diferença, em tais exemplos de geminação que mantêm inalterada a urdidura, enquanto opõe o desenho da trama, deve-se ao fato que, nos dois últimos casos, a narrativa responsiva é interna ao texto e, neste útimo, é externa; mas a lógica é idêntica e consiste, no primeiro fragmento, na passagem do literal ao metafórico (o coração é efetivamente arrancado de Guiscardo, enquanto se apresenta, como fantasma de morte, comicamente salvo, para Ricciardo), e no segundo, na inserção de uma série de imagens que transcorre de um texto a outro, consentindo, por meio da inversão de trajetória, de reviravoltas decisivas da narrativa, uma conclusão positiva. A questão que se deve fazer é, então, a seguinte: para individuar a fonte de um autor malicioso como Boccaccio é suficiente procurar os antecedentes presentes em cada uma das narrativas? Ou ainda, não seria preciso, e não só neste caso, prestar atenção também às inserções específicas, sobre as quais, de fato, se enreda o resto da narração? A resposta é óbvia, mas o caminho a percorrer está só no início.

Percebe-se que o percurso transcorrido aqui se baseia em poucos exemplos, aptos, porém,

41 “A leoa feroz saciou sua sede na água e, de volta à floresta, encontrou por acaso o delicado véu abandonado no chão, e rasgou-o com a boca suja de sangue." 
a ilustrar alguns recursos dos modelos utilizados por Boccaccio, a fim de percorrer novos caminhos narrativos. De qualquer forma, eles confirmam o quanto se deve trabalhar ainda para compreender a riqueza e a complexidade subjacente ao projeto do Decameron. $\mathrm{O}$ aspecto problemático da narração boccacciana valoriza a precisão da declaração de Benjamin (1962, p. 241-242, 251), para quem o romance e o conto se contrapõem, pois com o primeiro relaciona-se o "sentido da vida" e com o segundo a "moral da história" em um exercício de interpretação ininterrupto; o que encontra no Decameron sua possibilidade mais radical de verificação. Em todo caso, não nos engane a amplidão da entrada. Dado o caráter elusivo da coletânea, a facilidade de acesso, que pode esconder armadilhas culturalmente insidiosas, depende do uso responsável que cada leitor deve saber fazer do livro.

Tradução Doris N. Cavallari e Valéria Vicentini

\section{Referências bibliográficas}

BARBI, M. Sul testo del 'Decameron'. In La nuova filologia e l'edizione dei nostri scrittori, da Dante al Manzoni. Firenze: Sansoni, 1973.

BATTAGLIA RICCI, L. Ragionare nel giardino. Boccaccio e i cicli pittorici del «Trionfo della morte». Roma: Salerno 1987.

BATTAGLIA RICCI, L. Boccaccio. Roma: Salerno, 2000.

BATTAGLIA RICCI, L. Edizioni d'autore, copie di lavoro, interventi di autoesegesi: testimonianze trecentesche. In "Di mano propria". Gli autografi dei letterati italiani, Atti del Convegno Internazionale di Forlì, 24-27 novembre 2008, a cura di Guido Baldassarri, Matteo Motolese, Paolo Procaccioli, Emilio Russo. Roma: Salerno, 2010. p. 123-157.

BATTAGLIA RICCI, L. Scrivere un libro di novelle. G. Boccaccio autore, lettore, editore. Ravenna: Longo, 2013.

BENJAMIN, W. Il narratore. Considerazioni sull'opera di N. Leskov. In Angelus Novus. Saggi

e frammenti. Traduzione e introduzione di Renato Solmi. Torino: Einaudi, 1962. p. 235-260.

BERLIN, I. Il riccio e la volpe e altri saggi. A cura di Henry Hardy e Aileen Kelly, Introduzione di Aileen Kelly. Milano: Adelphi, 1998

BERNARDO DI CHIARAVALLE, SANTO. Patrologia latina, a cura di J.-P. Migne, vol. 183. Parigi: 


\section{J.-P. Migne, 1844-1855.}

BETTINZOLI, A. Per una definizione delle presenze dantesche nel 'Decameron'. I. I registri 'ideologici', lirici, drammatici. Studi sul Boccaccio, v. XIII, 1981-1982, p. 267-326.

BETTINZOLI, A. Per una definizione delle presenze dantesche nel 'Decameron'. II. Ironizzazione e espressivismo antifrastico-deformatorio. Studi sul Boccaccio, v. XIV, 1983-1984, p. 209-240.

BOCCACCIO, G. Decameron. A cura di Maurizio Fiorilla, illustrazioni di Mimmo Paladino. Roma: Istituto della Enciclopedia Italiana, 2011.

BOCCACCIO, G. Decameron. A cura di Vittore Branca. Torino: Einaudi, 1980.

BOCCACCIO, G. Decamerón. Edición de María Hernández Esteban, Traducción de María Hernández Esteban. Madrid: Catedra, 1994.

BOCCACCIO, G. Decameron. Introduzione, note e repertorio di Cose (e parole) del mondo di Amedeo Quondam, Testo critico e Nota al teso a cura di Maurizio Fiorilla, Schede introduttive e notizia biografica di Giancarlo Alfano. Milano: BUR Classici, 2013.

BOCCACCIO, G. Elegia di madonna Fiammetta. A cura di Carlo Delcorno. In BRANCA, V. (a cura di). Tutte le opere di G. Boccaccio. Milano: Mondadori, 1994. v. V, t. II, p. 3-412.

BOCCACCIO, G. Esposizioni sopra la Comedia di Dante. A cura di Giorgio Padoan. In BRANCA, V. (a cura di). Tutte le opere di G. Boccaccio. Milano: Mondadori, 1965. v. VI.

BRAGANTINI, R. Ingressi laterali al Trecento maggiore. Dante, Petrarca, Boccaccio. Napoli: Liguori, 2012.

BRAGANTINI, R. La spola del racconto: dal proverbio alla novella, e viceversa. In Il proverbio nella letteratura italiana dal XV al XVII secolo, Atti delle giornate di studi, 5-6 dicembre 2012, Università Roma 3-Fondazione Marco Besso. Manziana (Roma): Vecchiarelli, 2014.

BRESCHI, G. Il ms. Parigino it. 482 e le vicissitudini editoriali del 'Decameron'. Postilla per A. Rossi, Medioevo e Rinascimento, XVIII/n.s. XV, 2004.

CHERCHI, P. L'onestade e l'onesto raccontare del 'Decameron'. Fiesole: Cadmo, 2004.

CONTE, A. (a cura di). Il Novellino. Presentazione di Cesare Segre. Roma: Salerno, 2001.

CONTINI, G. Dante come personaggio-poeta della 'Commedia'. In . Varianti e altra linguistica.

Una raccolta di saggi (1938-1968). Torino: Einaudi, 1970. p. 335-361.

COSTANTINI, A. M. Studi sullo Zibaldone Magliabechino. II. Il florilegio senechiano. Studi sul Boccaccio, v. VIII, 1974, p. 79-126.

CURSI, M. Il 'Decameron': scritture, scriventi, lettori. Storia di un testo. Roma: Viella, 2007.

CURSI, M. La scrittura e i libri di G. Boccaccio. Roma: Viella, 2013. 
CURSI, M.; FIORILlA, M. G. Boccaccio. In BRUNETTI, G., FIORILLA, M., PETOLETTI, M. (a cura di). Autografi dei letterati italiani. Le Origini e il Trecento. Roma: Salerno, 2013, t. I, p. 43-103.

DELCORNO, C. Note sui dantismi nell' 'Elegia di Madonna Fiammetta'. In Studi sul Boccaccio, v. XI, 1979, p. 251-294.

DELCORNO, C. Ironia/parodia. In BRAGANTINI, R.; FORNI, P. M. (a cura di). Lessico critico decameroniano. Torino: Bollati Boringhieri, 1995. p. 162-191.

DORANDI, T. Laertiana. Capitoli sulla tradizione manoscritta e sulla storia del testo delle 'Vite dei filosofi' di Diogene Laerzio. Berlin; NewYork: de Gruyter, 2009.

DRONKE, P. Dante e le tradizioni latine medievali. Bologna: il Mulino, 1990.

FILOSA, E. Tre studi sul De mulieribus claris. Milano: LED, 2012.

FIORILLA, M. Per il testo del 'Decameron'. In L'Ellisse, V, 2010, p. 9-38.

FIORILLA, M. Ancora per il testo del 'Decameron'. In L'Ellisse, VIII, 2013, 1, p. 75-90.

FORNI, P. M. Forme complesse nel Decameron. Firenze: Olschki, 1992.

FORNI, P. M. Parole come fatti. La metafora realizzata e altre glosse al 'Decameron'. Napoli: Liguori, 2008 .

FUMAGALLI, E. Boccaccio e Dante. In ROBERTIS, T. et al. (a cura di). Boccaccio autore e copista. Firenze: Mandragora, 2013. p. 25-31 (Catalogo della mostra Boccaccio autore e copista, Firenze, Biblioteca Medicea Laurenziana, 11 ottobre 2013-11 gennaio 2014).

GRIGNASCHI, M. Lo pseudo Walter Burley e il 'Liber de vita et moribus philosophorum'. In Medioevo, 16, 1990, p. 131-190.

HOLLANDER, R. Boccaccio's Dante and the Shaping Force of Satire. Ann Arbor: University of Michigan Press, 1997.

KAHNEMAN, D. Thinking, Fast and Slow. New York: Farrar, Straus and Giroux, 2011.

KNUST, H. (a cura di). Gualteri Burlaei Liber de vita et moribus philosophorum, mit einer altspanischen Übersetzung der Eskurialbibliothek. Tübingen: Bibliothek des Litterarischen Vereins in Stuttgart, 1886; Frankfurt a/Main: Minerva, 1964, Unveränderter Nachdruck.

MALAGNINI, F. Il sistema delle maiuscole nell'autografo berlinese del 'Decameron' e la scansione del mondo commentato. Studi sul Boccaccio, v. XXXI, 2003, p. 31-69.

NOCITA, T. Per una nuova paragrafatura del testo del 'Decameron'. Appunti sulle maiuscole del cod. Hamilton 90 (Berlin, Staatsbibliothek Preussischer Kulturbesitz). Critica del testo, II/3, 1999, p. 925-934.

PACIUCCI, M. Elementi della rielaborazione del sacro in Boccaccio. La novella VIII 7: Elena e lo scolare. In “Tout est dit”. Teoria, problemi, fenomeni della riscrittura, Atti del Seminario di studi del 
Dottorato in Italianistica e Spettacolo, Roma 17-18 giugno 2009, a cura di Renzo Bragantini, Studi (e testi) italiani, 26 (2010), p. 79-96.

PADOAN, G. Sulla genesi e la pubblicazione del 'Decameròn'. In Il Boccaccio, le Muse, il Parnaso e l'Arno. Firenze: Olschki, 1978, p. 93-121.

PETOLETTI, M. Il 'Chronicon' di Benzo d'Alessandria e i classici latini all'inizio del XIV secolo. Edizione critica del libro XXIV: 'De moribus et vita philosophorum'. Milano: Vita e Pensiero, 2000.

PETRARCA, F. Canzoniere. A cura di Marco Santagata. Edizione commentata, nuova edizione aggiornata. Milano: Mondadori, 2004.

PETRARCA, F. Il codice degli abbozzi: edizione e storia del manoscritto Vaticano latino 3196. A cura di Laura Paolino. Milano; Napoli: Ricciardi, 2000.

PETRARCA, F. Le familiari. Traduzione e cura di Ugo Dotti, testo critico di Vittorio Rossi e Umberto Bosco, collaborazione di Felicita Audisio, 5 t. Torino: Aragno, 2004-2009.

PETRARCA, F. Le "Senili" secondo l'edizione Basilea 1581. A cura di Marziano Guglielminetti, con un contributo critico di Mario Martelli e una nota di Patrizia Pellizzari. Savigliano (CU): L'Artistica, 2006.

PETRUCCI, A. Il libro manoscritto. In Letteratura italiana, diretta da Alberto Asor Rosa, v. II, Produzione e consumo. Torino: Einaudi, 1983, p. 497-524.

PICONE, M. L'invenzione della novella italiana. Tradizione e innovazione. In La novella italiana, Atti del Convegno di Caprarola, 19-24 settembre 1988, 2 t. Roma: Salerno, 1989, I, p. 119-154.

POZZI, G. Petrarca, i Padri e soprattutto la Bibbia. In . Alternatim. Milano: Adelphi, 1996, p. 143-189.

RAFTI, P. "Lumina dictionum". Interpunzione e prosa in G. Boccaccio. IV. Studi sul Boccaccio, v. XXIX, 2001, p. 3-66.

SANTAGATA, M. I frammenti dell'anima. Storia e racconto nel Canzoniere di Petrarca. Bologna: il Mulino, 2004.

SEGRE, C. Comicità strutturale nella novella di Alatiel. In Le strutture e il tempo. Torino: Einaudi, 1974, p. 145-159.

VELLI, G. Seneca nel 'Decameron'. Giornale storico della letteratura italiana, CLXVIII, 1991, p. 321-334.

VELLI, G. Memoria. In BRAGANTINI, R.; FORNI, P. M. (a cura di ). Lessico critico decameroniano. Torino: Bollati Boringhieri, 1995, p. 222-248.

VITALE, M.; BRANCA, V. Il capolavoro del Boccaccio e due diverse redazioni, 2 t.; I: Vitale, Maurizio, La riscrittura del 'Decameron'. I mutamenti linguistici; II: Branca, Vittore, Variazioni narrative e stilistiche. Venezia: Istituto Veneto di Scienze, Lettere ed Arti, 2002. 